\title{
Tinjauan Yuridis Terhadap Penyelundupan Hukum dalam Perkawinan Campuran
}

\author{
Lutfiana Dwi Mayasari \\ Institut Agama Islam Riyadlotul Mujahidin Ngabar Ponorogo \\ E-mail: luthfiana.mcw@gmail.com
}

\begin{abstract}
Abstrak: Celah hukum pada pasal 56 UU No 1/1974 acapkali dijadikan salah satu alternatif dan jalan pintas formalisasi pernikahan beda agama di Indonesia. Penyelundupan hukum dalam perkawinan beda agama yang dilakukan tersebut justru dilindungi oleh regulasi. Seperti contoh kasus Dimas Anggara dan Nadine Chandrawinata, perkawinan Yuni Shara dan Henry Siahaan, dan perkawinan sejenis antara pasangan gay Ragil Mahardika dan suaminya Frederik Vollert yang berasal dari Jerman. Penelitian ini menggunakan penelitian deskriptif, dan analisis yuridis normatif. Melalui analisis kasus penyelundupan hukum, disimpulkan bahwa terjadi kekosongan hukum. Tidak ada aturan khusus yang mengatur mengenainya.Menyamakan perkawinan campuran dengan kasus penyelundupan hukum jelas bertentangan dengan amanat konstitusi. Perkawinan yang dilakukan oleh pelaku penyelundupan hukum tidak sah baik secara agama maupun secara administratif hukum perkawinan nasional Indonesia.

Kata kunci: Penyelundupan hukum, perkawinan campuran, perjanjian internasional.
\end{abstract}

\section{Pendahuluan}

Seiringan dengan berkembangnya masyarakat, permasalahan yang terjadi semakin kompleks. Berkaitan dengan perkawinan, belakangan ini sering tersiar dalam berbagai media terjadinya perkawinan yang dianggap problematis dalam kehidupan bermasyarakat. Sebagai contoh, perkawinan campuran, perkawinan sejenis, kawin kontrak, dan perkawinan antara pasangan yang memiliki keyakinan (agama) yang berbeda. Walaupun perkawinan campuran dan perkawinan beda-agama sama sekali berbeda, bukan tidak mungkin pada saat yang sama perkawinan campuran juga menyebabkan perkawinan beda-agama. ${ }^{1}$

Berlandasakan Pasal 56 UU No 1/1974, banyak WNI yang melakukan perkawinan di luar negeri untuk mengesahkan perkawinan problematis

\footnotetext{
${ }^{1}$ http://hukumonline.com/detail.asp?id=15656\&cl=Berita., diakses pada 5 Agustus 2019.
} 
di Indonesia sebagaimana disebut diatas. Seperti perkawinan beda agama yang dilakukan oleh Dimas Anggara dan Nadine Chandrawinata, ${ }^{2}$ dan perkawinan sejenis antara pasangan gay Ragil Mahardika, dan suaminya asal Jerman, Frederik Vollert.

Perkawinan di luar negeri yang bertujuan untuk mengesahkan perkawinan yang dilarang di Indonesia disebut dengan penyelundupan hukum. Penyelundupan hukum terjadi jika ada seseorang atau suatu pihak yang untuk mendapatkan berlakunya hukum asing, menghindarkan pemakaian hukum nasional, dengan tujuan untuk menghindarkan suatu syarat atau suatu akibat hukum tertentu yang tidak dikehendaki, ataupun untuk mewujudkan atau menciptakan suatu akibat hukum yang dikehendaki. Seseorang melakukan penyelundupan hukum dengan tujuan agar diberlakukan hukum yang lain dari hukum yang seharusnya digunakan. ${ }^{3}$

Penyelundupan hukum ini disebabkan karena masih lemahnya UU No.1 tahun 1974 dalam mengatur permasalahan ini. Pasal 56 UU No 1/1974 memberikan peluang pada WNI untuk melakukan kejahatan tersebut. Dalam Pasal ini dijelaskan yang pada intinya menyatakan pernikahan antar sesama warga negara Indonesia (WNI) atau seorang WNI dengan warga negara asing di luar negeri sah karena mengacu pada hukum yang berlaku di negara tempat pernikahan itu berlangsung (lex loci celebration). ${ }^{4}$ Perkawinan antar agama dan perkawinan sejenis yang dilakukan di negara yang menganggap perkawinan tersebut sah, maka akan dinyatakan sah pula secara administrative di Indonesia.

Pasal 56 UU No 1/1974 bukanlah pasal yang berdiri sendiri, ada pasal lain yang seharusnya ditaati sebelum menetapkan lex locus celebration. Yaitu pasal 2 ayat (1) UU No 1 Tahun 19745. Bagir Manan menyatakan bahwa perkawinan yang sah adalah perkawinan yang memenuhi ketentuan pasal 2 ayat (1) Undang-Undang No 1 Tahun 1974, yaitu sah menurut agama, yang mempunyai akibat hukum yang sah pula. ${ }^{6}$ Karena

\footnotetext{
${ }^{2}$ https://www.suara.com/entertainment/2021/05/30/102405/7-pasangan-artismenikah-di-luar-negeri-gegara-beda-agama-ada-yang-akhirnya-seiman?page=all,

3 Bayu Seto Hardjowahono, Dasar-Dasar Hukum Perdata Internasional (Bandung: PT Citra Aditya Bakti, 2006), hlm. 128.

4 Penjelasan UU No 1 Tahun 1974 pasal 56

5 Neng Djubaida, Pencatatan Perkawinan dan Perkawinan Tidak Dicatat (Jakarta: Sinar Grafika, 2010), hlm. 416.

${ }^{6}$ Bagir Manan, Keabsahan dan Syarat-Syarat Perkawinan Antar Orang Islam Menurut UU No 1Tahun 1974" makalah disampaikan dalam Seminar Nasional dengan Tema Hukum
} 
perkawinan antar agama dan perkawinan sejenis dilarang oleh agama, maka seharusnya perkawinan diluar negeri tersebut dinyatakan tidak sah di Indonesia meskipun dinyatakan sah di negara dimana perkawinan tersebut berlangsung.

Sedangkan Hukum Perdata Internasional tidak mengatur uniformitas hukum dalam menyelesaikan permasalahan penyelundupan hukum ini. Diterima atau tidaknya suatu akibat yang disebabkan karena penyelundupan hukum diatur oleh sistem-sistem hukum yang diarahkan kepada hukum nasional yang berlaku di negara tersebut. ${ }^{7}$ Yang dalam konteks keindonesiaan menggunakan UU No 1 Tahun 1974. Sedangkan dalam tubuh undang-undang perkawinan itu sendiri terdapat kontradisi antar pasal 56 UU No 1/1974 dan pasal 2 dalam UU yang sama.

Oleh karena itu, melihat bahwa penyelundupan hukum merupakan salah satu alternatif dan jalan pintas formalisasi perkawinan problematis bagi WNI, maka peneliti tertarik untuk membahas tinjauan yuridis terutama Undang-Undang Perkawinan Indonesia terhadap penyelundupan hukum dalam perkawinan bagi WNI, dan keabsahan penyelundupan hukum dalam perkawinan WNI yang dilakukan diluar negeri.

\section{Metode Penelitian}

Dalam penelitian ini menggunakan jenis penelitian yuridis normatif. Dengan menggunakan pendekatan perundang-undangan dan pendekatan kasus. ${ }^{8}$ Pendekatan perundang-undangan adalah pendekatan dengan menggunakan legislasi dan regulasi. Pendekatan kasus, menitik beratkan kepada ratio decidendi, yaitu alasan-alasan hukum yang digunakan oleh hakim dalam memutus sebuah perkara.

\section{Hasil dan Pembahasan}

\section{Status Kasus Perkawinan Yuni Shara dan Henry Siahaan}

Yuni Shara (lahir dengan nama Wahyu Setyaning Budi di Malang, Jawa Timur, 3 Juni 1972) adalah seorang penyanyi berkebangsaan Indonesia. Pada 18 Oktober 1997 menikah dengan pengusaha Henry Siahaan, duda beranak 2, yang juga mantan suami artis dan penyanyi Nur

Keluarga dalam Sistem Hukum Nasional antara Realitas dan Kepastian Hukum yang diselenggarakan MA RI, pada tanggal 1 Agustus 2009.

7 Sudargo Gautama, Hukum Perdata Internasional Indonesia, jilid II bagian 3 buku ke-4 (Bandung: PT Alumni, 1998), hlm. 295.

8 Peter Mahmud Marzuki, Penelitian Hukum, (Jakarta: Kencana Prenada Media Group, 2011), hlm. 118-119. 
Afni Octavia. ${ }^{9}$ Namun karena keduanya berbeda agama, perkawinan mereka tersebut tidak dapat dicatatkan secara resmi oleh Kantor Catatan Sipil. Yuni adalah pemeluk agama Islam, sedangkan Henry beragama Kristen. Hal itu pula yang membuat pernikahan mereka tidak berpayung hukum selama 5 tahun.

Karena adanya penolakan tersebut, kemudian pasangan Yuni-Henry mencoba untuk memperoleh legalitas perkawinannya di sejumlah negara yang berhasil didapatkan sejumlah selebriti WNI lainnya, yaitu Singapura, dan Hong Kong. Karena sesuai dengan amanat pasal 56 bahwa segala bentuk pernikahan yang dilaksanakan diluar negeri dan sah menurut negara tempat dilangsungkannya perkawinan, maka perkawinan tersebut dianggap sah oleh pemerintah Indonesia.

District Registrar's Office, Perth, Western Australia, pada tanggal 7 Agustus 2002, mengeluarkan surat nikah yang resmi dan empat hari kemudian pasangan ini mendaftarkan pernikahannya di Indonesia selanjutnya dicatatkan di Indonesia. ${ }^{10}$ Dan perkawinan mereka dianggap sah sesuai dengan ketentuan regulasi di Indonesia.

Secara kronologis Yuni Shara dan Henry Siahaan melangsungkan perkawinan di District Registrar's Office, Perth, Western Australia karena alasanalasan berikut:

1. Perkawinan mereka tidak dapat dilangsungkan di Indonesia karena menurut pasal 2 UUP Indonesia, perkawinan dilaksanakan sesuai dengan ajaran agama masing-masing. Sedangkan mereka adalah pasangan beda agama.

2. Selama 5 tahun, mereka hidup bersama tanpa adanya ikatan perkawinan yang sah secara administrasi kenegaraan.

3. Perkawinan mereka dianggap tidak sah secara hukum negara, karena tidak diregistrasi di Catatan Sipil maupun di KUA (Kantor Urusan Agama), sehingga banyak memunculkan opini publik.

4. Memerhatikan situasi ini, maka kedua belah pihak menikah berdasarkan hukum Australia dan melangsungkan perkawinan di Perth, Western Australia. Karena negara tersebut melegalkan perkawinan antar agama, dan bisa mengeluarkan akta nikah. Sehingga perkawinan antara Yuni Shara dan Henry Siahaan sah secara hukum yang berlaku di Perth, Western Australia.

\footnotetext{
${ }^{9}$ Henry Siahan - Yuni Shara, Bicara Soal Anak dan Pernikahan, diakses 6 Januari 2014

${ }^{10}$ Yuni Shara-Henry Siahaan: Akhirnya Resmi Menikah, diakses 6 Januari 2014
} 
5. Akta perkawinan yang dikeluarkan oleh District Registrar's Office Perth, Western Australia inilah yang dijadikan bukti untuk meregistrasi perkawinan mereka di Catatan Sipil Indonesia.

Tinjauan Yuridis terhadap Penyelundupan Hukum dalam Perkawinan

a. Penyelundupan Hukum dalam Perkawinan ditinjau dari hukum positif Indonesia dan Hukum Internasional

Selain yang dialami oleh Yuni Shara, masih ada beberapa orang yang melakukan penyelundupan hukum. Misalnya, pasangan artis lain Amara dan Francois Mohede yang mendahului Yuni menikah di luar negeri, atau pasangan Bucek Depp-Unique Priscilla yang menikah menurut hukum Islam dan Kristen. Kemudian, pasangan Melly Manuhutu-Prakacha Kashmir dengan mengajukan ijin nikah ke pengadilan negeri, dan masih banyak lagi.

Secara normatif, agama melarang pernikahan beda iman, baik agama Kristiani maupun Islam. Larangan tersebut tidak datang dari negara melainkan dari agama. Sepanjang tidak ada pengesahan agama, adalah tidak mungkin catatan sipil mencatat sebuah perkawinan. ${ }^{11}$ Sikap yang diambil pegawai Kantor Catatan Sipil tersebut bersumber dari penafsiran terhadap Pasal 2 ayat (1) UU No.1 Tahun 1974 tentang Perkawinan. Menurut ketentuan hukum tersebut, perkawinan yang sah adalah perkawinan yang dilakukan menurut hukum masing-masing agama dan kepercayaannya. Bagi pasangan yang tidak mengikuti ketentuan pasal dalam undang-undang tersebut, harus siap menerima konsekuensi hukumnya.

Namun dalam praktiknya banyak pasangan beda agama yang bisa berakhir di pelaminan. Setidaknya ada 4 "solusi" bagi pasangan beda agama yang ingin menikah menurut Guru Besar Hukum Perdata Universitas Indonesia Prof. Wahyono Darmabrata, yakni:

1. Meminta penetapan pengadilan, Meminta penetapan pengadilan terakhir kali dilakukan oleh Andi Vonny Gani pada 1989. Jika RUU Adminduk yang saat ini sedang dibahas DPR disahkan, akan lebih banyak lagi penetapan pengadilan dimohonkan. Ketua Konsorsium Catatan Sipil Lies Sugondo menyatakan bahwa solusi penetapan pengadilan yang disarankannya turut dimasukkan dalam RUU Adminduk.

\footnotetext{
${ }^{11}$ Sudhar Indopa, pegawai Kantor Catatan Sipil DKI Jakarta, disampaikan dalam seminar tentang perkawinan beda agama yang diselenggarakan Lembaga Kajian Hukum Perdata Fakultas Hukum Universitas Indonesia Mei 2006.
} 
2. Pernikahan dilakukan menurut masing-masing agama, Perkawinan menurut masing-masing agama merupakan interpretasi lain dari pasal 2 ayat (2) UU No. 1 Tahun 1974 tentang Perkawinan. Pagi menikah sesuai agama laki-laki, siangnya menikah sesuai dengan agama perempuan.

3. Penundukan sementara pada salah satu hukum agama, Penundukan diri terhadap salah satu hukum agama mempelai mungkin lebih sering digunakan. Dalam agama Islam, diperbolehkan laki-laki Islam menikahi wanita non-Islam, yang termasuk ahlul kitab. Ayat Al-Quran inilah yang dipraktekkan sungguh oleh lembaga-lembaga seperti Paramadina, Wahid Institute, dan Indonesian Conference on Religion and Peace (ICRP), bahkan diperluas jadi memperbolehkan kawin beda agama bagi wanita muslim. Kasus yang cukup terkenal adalah perkawinan artis Deddy Corbuzier dan Kalina, pada awal 2005 lalu. Deddy yang Katolik dinikahkan secara Islam oleh penghulu pribadi yang dikenal sebagai tokoh dari Yayasan Paramadina.

4. Menikah di luar negeri, melakukan perkawinan di luar negeri, berarti tunduk pada hukum di luar negeri. Pasangan tersebut mendapat akte dari negara itu, kemudian akte di bawa pulang untuk dicatatkan saja. Artinya tidak memperoleh akte lagi dari negara.

Dalam memahami perkawinan beda agama menurut undangundang perkawinan ada tiga penafsiaran yang berbeda. Pertama, penafsiran yang berpendapat bahwa perkawinan beda agama merupakan pelanggaran terhadap Undang-Undang No. 1 Tahun 1974 Pasal 2 ayat (1) jo Pasal 8 (f).

Pendapat kedua, bahwa perkawinan antar agama adalah sah dan dapat dilangsungkan, karena telah tercakup dalam perkawinan campuran, dengan argumentasi pada Pasal 57 tentang perkawinan campuran yang menitik beratkan pada dua orang yang di Indonesia tunduk pada hukum yang berlainan, yang berarti pasal ini mengatur perkawinan antara dua orang yang berbeda kewarganegaraan juga mengatur dua orang yang berbeda agama.

Pendapat ketiga bahwa perkawinan antar agama sama sekali tidak diatur dalam Undang-Undang No. 1 Tahun 1974, oleh karena itu berdasarkan Pasal 66 Undang-Undang No. 1 Tahun 1974 maka 
persoalan perkawinan beda agama dapat merujuk pada peraturan perkawinan campuran, karena belum diatur dalam undang-undang perkawinan. ${ }^{12}$

Ketiga pendapat ini perlu dikaji lebih mendalam lagi, mengingat regulasi perkawinan campuran diluar negeri dalam pasal 56 itu sendiri sangat tidak mengakomodir terhadap perkawinan campuran. Hal ini ditegaskan oleh Nurul Hasanah dalam skripsinya. ${ }^{13}$ Bagaimana mungkin suatu regulasi yang tidak mampu mengakomodir segala hal yang berhubungan dengannya, justru dijadikan rujukan untuk permasalahan yang belum mempunyai regulasi, meskipun mempunyai kesamaan. Jika hal ini dibiarkan tentunya akan sangat membahayakan.

Dari empat solusi yang ditawarkan Guru Besar Hukum Perdata Universitas Indonesia Prof. Wahyono Darmabrata terkait pengesahan perkawinan problematis di Indonesia, perkawinan diluar negeri lebih banyak dipilih. Hal ini dilakukan karena perkawinan diluar negeri tidak membutuhkan administrasi serumit administrasi jika pasangan tersebut melangsungkan perkawinan di Indonesia menggunakan solusi yang lain.

Perkawinan diluar negeri dianggap solusi pelegalan perkawinan antar agama karena memang hal ini dilindungi oleh Undang-Undang Perkawinan Indonesia. Tepatnya pasal 56 UU No 1 Tahun 1974, sebagai berikut: ${ }^{14}$

1) Perkawinan di Indonesia antara dua orang warganegara Indonesia atau seorang warganegara Indonesia dengan warga negara Asing adalah sah bilamana dilakukan menurut hukum yang berlaku di negara dimana perkawinan itu dilangsungkan dan bagi warganegara Indonesia tidak melanggar ketentuan Undang-undang ini.

2) Dalam waktu 1 (satu) tahun setelah suami istri itu kembali di wilayah Indonesia, surat bukti perkawinan mereka harus

\footnotetext{
12 Ahmad Sukarja, Perkawinan Berbeda Agama Menurut Hukum Islam, Editor Chuzaimah T Yanggo, \& Hafiz Anshary, Problematika Hukum Islam Kontemporer (Jakarta: PT Pustaka Firdaus, 1996), hlm. 17-18.

${ }^{13}$ Nurul Hasanah, Konstelasi Perkawinan Campuran Dalam Peraturan Perundang-Undangan Di Indonesia, skripsi, (Malang: Fakultas Syariah, Universitas Islam Negeri Maulana Malik Ibrahim Malang, 2010)

14 Pasal 56 UUP No 1 Tahun 1974
} 
didaftarkan di Kantor Pencatat perkawinan tempat tinggal mereka.

Meskipun UU Perkawinan tidak memperbolehkan kawin beda agama, tetapi Kantor Catatan Sipil bisa menerima pencatatan perkawinan beda agama yang dilakukan di luar negeri.

Permasalahan penyelundupan hukum ini bukan hanya menimbulkan perselisihan (dispute) antar para pihak, tetapi juga berdampak kepada seluruh masyarakat dalam negara hukum yang bermartabat dan ini merupakan suatu jati diri bangsa yang dianggap baik apabila mampu mengakomodir seluruh kepentingan masyarakat.

Ambiguitas dan upaya legalisasi penyeludupan hukum di Indonesia sangat tersusun rapi dibalik regulasi. Perbuatan yang sebenarnya melanggar aturan di Indonesia, justru dipolitisasi sedemikian rupa dengan menghalalkan penyelundupan hukum guna melindungi status hukum WNI.

Dalam pandangan hukum perdata Internasional, suatu perbuatan yang dilakukan di suatu negara asing dan diakui sah di negara asing itu, akan dapat dibatalkan oleh negara forum atau tidak diakui oleh forum bila perbuatan itu dilaksanakan di negara asing yang bersangkutan dengan tujuan untuk menghindarkan diri dari aturanaturan lex fori yang akan melarang perbuatan semacam itu dilaksanakan di wilayah forum. ${ }^{15}$ Kegel juga berpendapat bahwa hukum asing dapat dikesampingkan jika dianggap bertentangan dengan "the untouchable part" dari lex fori itu. ${ }^{16}$

Hal ini didukung dengan prinsip yang digunakan oleh ketertiban umum (public order).

Jika pemberlakuan hukum asing dapat menimbulkan akibatakibat berupa pelanggaran terhadap sendi-sendi pokok hukum setempat (lex fori), hukum asing itu dapat dikesampingkan dengan dasar "demi kepentingan umum" atau "demi ketertiban umum". 17

Perkawinan dilakukan oleh Yuni Shara di District Registrar's Office, Perth, Western Australia adalah untuk menghindari berlakunya pasal 2 UUP. Sudah barang tentu, Indonesia sebagai

\footnotetext{
15 Bayu Seto Hardjowahono, hlm. 122.

${ }^{16}$ Hartono Sunaryati, Pokok-Pokok Hukum Perdata Internasional, cet.IX (Bandung:Binacipta, 1976), hlm 117.

17 Bayu Seto Hardjowahono, hlm. 123.
} 
wilayah forum seyogyanya membatalkan perkawinan tersebut, meskipun secara administrasi mereka memenuhi syarat. Fungsi doktrin ketertiban umum ini adalah untuk melindungi sistem hukum yang seharusnya berlaku.

Menurut analisis penulis, terjadinya ambiguitas dalam regulasi penyelundupan hukum ini dikarenakan kesalahan dalam penggunaan regulasi. Tidak ada regulasi khusus yang mengatur tentang konsekwensi hukum terhadap pelaku penyelundupan hukum. Keabsahan pelaku penyelundupan hukum diukur dari pasal 56 UUP, yang sebenarnya mengatur tentang perkawinan diluar negeri, dan berlaku pengecualian untuk pelaku penyelundupan hukum.

Yang menyamakan antara penyelundupan hukum dan perkawinan campuran hanyalah pada pelaksaan perkawinan yang dilakukan diluar negeri. Meskipun ada kesamaan, namun kasus penyelundupan mempunyai makna yang berbeda dengan perkawinan campuran. Oleh karena itu, penggunaan pasal 56 UUP tidak sesuai untuk dijadikan acuan dalam kasus penyelundupan hukum.

UUP yang berlaku di Indonesia disusun pada tahun 1974, sedangkan kajian mengenai penyelundupan itu sendiri baru dikenal oleh Hukum Perdata Internasional pada tahun 2006, dimana sebelumnya penyelundupan masuk dalam kajian Ketertiban Umum. Seharusnya UU Perkawinan di Indonesia responsive terhadap perkembangan social dan perkembangan kasus yang terus bermutasi seiring dengan perkembangan waktu dan teknologi. Agar mampu menjadi rujukan dan menjadi solusi akhir yang solutif bagi setiap kasus yang muncul.

b. Kekosongan Hukum dalam Penyelundupan Hukum Perkawinan di Indonesia

Penegakan dan penerapan hukum khususnya di Indonesia seringkali menghadapi kendala berkaitan dengan perkembangan masyarakat. Berbagai kasusyang telah terjadi menggambarkan sulitnya penegak hukum atau aparat hukum mencari cara agar hukum dapat sejalan dengan norma masyarakat yang ada. Namun perkembangan masyarakat lebih cepat dari perkembangan aturan perundang-undangan, sehingga perkembangan dalam masyarakat tersebut menjadi titik tolak dari keberadaan suatu peraturan. 
Dalam kehidupan bermasyarakat memang diperlukan suatu sistem hukum untuk menciptakan kehidupan masyarakat yang harmonis dan teratur. Kenyataannya hukum atau peraturan perundang-undangan yang dibuat tidak mencakup seluruh perkara yang timbul dalam masyarakat sehingga menyulitkan penegak hukum untuk menyelesaikan perkara tersebut.

Asas legalitas yang kerap dianggap sebagai asas yang memberikan suatu kepastian hukum dihadapkan oleh realita bahwa rasa keadilan masyarakat tidak dapat dipenuhi oleh asas ini karena masyarakat yang terus berkembang seiring kemajuan teknologi. Perubahan cepat yang terjadi tersebut menjadi masalah berkaitan dengan hal yang tidak atau belum diatur dalam suatu peraturan perundang-undangan, karena tidak mungkin suatu peraturan perundang-undangan dapat mengatur segala kehidupan manusia secara tuntas sehingga adakalanya suatu peraturan perundangundangan tidak jelas atau bahkan tidak lengkap yang berakibat adanya kekosongan hukum di masyarakat.

Dalam praktik, tidak jarang dijumpai ada peristiwa yang belum diatur dalam hukum atau perundang-undangan, atau meskipun sudah diatur tetapi tidak lengkap dan tidak jelas. Oleh karena itu peraturan hukum yang tidak jelas harus dijelaskan, yang tidak lengkap harus dilengkapi dengan jalan menemukan hukumnya agar aturan hukumnya dapat diterapkan terhadap peristiwanya. ${ }^{18}$

Hal ini pula yang terjadi dalam regulasi perkawinan di Indonesia. Perkembangan tekhnologi, perkembangan masyarakat, dan perkembangan permasalahan yang terjadi semakin kompleks. Bahkan belakangan ini sering tersiar dalam berbagai media terjadinya perkawinan yang dianggap problematis dalam kehidupan bermasyarakat. Namun perkembangan ini tidak diiringi dengan perkembangan regulasi.

Dalam artian, regulasi yang ada dan berlaku sekarang justru out of date. Hal ini terbukti dengan maraknya penyelundupan hukum dalam perkawinan tidak diiringi dengan regulasi yang mengaturnya. Sehingga, segala perkawinan yang dilaksanakan diluar negeri dianggap sebagai perkawinan campuran. Tatkala terjadi penyelundupan hukum, maka regulasi yang digunakan adalah

${ }^{18}$ Sudikno Mertokusumo, Metode Penemuan Hukum (Yogyakarta:UII Press, 2006), hlm. 28 
regulasi perkawinan di luar negeri (pasal 56) dan regulasi perkawinan campuran (57).

Disini tampak bahwa terdapat kekosongan hukum dalam penyelundupan hukum perkawinan di Indonesia. Akibat yang ditimbulkan dengan adanya kekosongan hukum, terhadap hal-hal atau keadaan yang tidak atau belum diatur itu dapat terjadi ketidakpastian hukum (rechtsonzekerheid) atau ketidakpastian peraturan perundang-undangan di masyarakat yang lebih jauh lagi akan berakibat pada kekacauan hukum (rechtsverwarring), dalam arti bahwa selama tidak diatur berarti boleh, selama belum ada tata cara yang jelas dan diatur berarti bukan tidak boleh.

Hal inilah yang menyebabkan kebingungan (kekacauan) dalam masyarakat mengenai aturan apa yang harus dipakai atau diterapkan. Dalam masyarakat menjadi tidak ada kepastian aturan yang diterapkan untuk mengatur hal-hal atau keadaan yang terjadi. Pelaku merasa bahwa hal tersebut dilegalkan secara undang-undang formil.

Oleh karena itu, guna mewujudkan kepastian hukum dan mengatasi terjadinya kekosongan hukum maka dibutuhkan suatu penemuan hukum. ${ }^{19}$ Menurut John $\mathrm{Z}$ Laude, penemuan hukum adalah penerapan ketentuan pada fakta dan ketentuan tersebut kadangkala harus dibentuk karena tidak selalu terdapat dalam undang-undang yang ada. ${ }^{20}$

Di Indonesia, aliran penemuan hukum dikenal terutama dalam praktik peradilan dan mulai mendapatkan tempat setelah adanya peraturan perundang-undangan terutama yang mengatur tentang kekuasaan kehakiman secara substansial mengatur mengenai beberapa ketentuan yang memungkinkan kegiatan penemuan hukum dilakukan. ${ }^{21}$

Penemuan hukum merupakan proses pembentukan hukum oleh subjek atau pelaku penemuan dalam upaya menerapkan peraturan hukum umum terhadap peristiwanya berdasarkan kaidah-kaidah atau metode-metode tertentu yang dapat dibenarkan dalam ilmu hukum, seperti interpretasi, penalaran (redering), eksposisi (kontruksi

\footnotetext{
${ }^{19}$ Sudikno Mertokusumo, Metode Penemuan Hukum, hlm. 28.

${ }^{20} J o h n$ Z Loude, Menemukan Hukum Melalui Tafsir dan Fatwa (Jakarta:Bina Aksara, 1985), hlm.69.

21 Sudikno Mertokusumo, Metode Penemuan Hukum, hlm 32.
} 
hukum), dan lain-lain. Kaidah-kaidah atau metode-metode tersebut digunakan agar penerapan aturan hukum terhadap suatu peristiwa dapat dilakukan secara tepat dan relevan menurut hukum, sehingga hasil yang diperoleh dari proses tersebut juga dapat diterima dan dipertanggungjawabkan dalam ilmu hukum. ${ }^{22}$

Sedangkan solusi yang ditawarkan oleh peneliti dalam menghadapi kekosongan hukum dalam penyelundupan hukum perkawinan adalah dengan melakukan Rechtschepping (penciptaan hukum), yaitu menciptakan hukum yang sebelumnya tidak ada menjadi ada. ${ }^{23} \mathrm{Hal}$ ini dikarenakan hukum yang mengatur tentang penyelundupan hukum sebenarnya sudah ada secara eksplisit yaitu masuk dalam perkawinan campuran. Namun peraturan dalam perkawinan campuran tersebut tidak jelas dan kurang lengkap, sehingga harus diciptakan hukum baru sebagai penyempurna.

Penciptaan hukum dalam regulasi penyelundupan hukum perkawinan di Indonesia harus berdasarkan pada sistem hukum yang ada (system oriented). Oleh karena itu diperlukan kebijakan atau prakarsa dari Badan Pembentuk Perundangundangan, yang berdasarkan Undang-Undang Dasar Negara Republik Indonesia Tahun 1945 (UUD 1945 yang telah diamandemen) Pasal 20 ayat (1) dan (2) menyatakan bahwa "DPR memegang kekuasaan membentuk undang-undang" dan "setiap rancangan undang-undang dibahas oleh DPR dan Presiden untuk mendapat persetujuan bersama".

Pasal 5 UUD Negara RI Tahun 1945 menegaskan pula bahwa "Presiden berhak mengajukan rancangan undang-undang kepada DPR" dan "Presiden menetapkan peraturan pemerintah untuk menjalankan undang-undang sebagaimana mestinya".

Dalam hal ini berarti prakarsa atau kebijakan (political will) dari DPR dan Pemerintah (Presiden) memegang peranan yang sangat penting dalam menciptakan atau membentuk suatu undang-undang (lebih luas peraturan perundang-undangan) baik mengatur hal-hal atau keadaan yang tidak diatur sebelumnya maupun perubahan atau penyempurnaan dari peraturan perundang-undangan yang telah ada namun sudah tidak sesuai dengan perkembangan di masyarakat.

22 Sudikno Mertokusumo, Metode Penemuan Hukum, hlm 30.

${ }^{23}$ Mertokusumo, Sudikno, Penemuan Hukum Sebuah Pengantar (Yogyakarta:Liberty, 1998), hlm.36-37. 
Lebih lanjut dalam upaya mengatasi kekosongan hukum maka dalam pembentukan peraturan perundang-undangan berdasarkan Pasal 1 angka 1 UU No. 10 Tahun 2004 tentang Pembentukan Peraturan Perundang-undangan menyatakan bahwa "Pembentukan Peraturan Perundang-undangan adalah proses pembuatan peraturan perundang-undangan yang pada dasarnya dimulai dari perencanaan, persiapan, teknik penyusunan, perumusan, pembahasan, pengesahan, pengundangan, dan penyebarluasan".

Kemudian dalam Pasal 15 ayat (1) UU No. 10 Tahun 2004 ditegaskan bahwa "Perencanaan penyusunan Undang-Undang dilakukan dalam suatu Program Legislasi Nasional (Prolegnas)". Prolegnas itu sendiri menurut Pasal 1 angka 9 adalah "instrumen perencanaan program pembentukan Undang-Undang yang disusun secara berencana, terpadu dan sistematis".

Prolegnas menjadi salah satu dari mekanisme program legislasi. Karena disamping Prolegnas (pemerintah/eksekutif) yang menampung rencana-rencana legislasi dari departemendepartemen/LPND, juga terdapat mekanisme program legislasi yang dikelola oleh Badan Legislasi (Baleg) DPR. Bahkan juga ada program legislasi yang dikelola oleh masyarakat (organisasi profesi dan lembaga swadaya masyarakat).

Keabsahan Penyelundupan Hukum Dalam Perkawinan Bagi WNI Menurut Hukum Positif Indonesia

Peraturan perkawinan campuran di Indonesia sebelum UUP lebik baik dan mudah dilaksanakan (GHR S. 1898 - 158), karena dimungkinkan berbagai perbedaan dicampur dalam keluarga melalui perkawinan yang sah. Sejak tahun 1974 di Indonesia peraturasn perkawinan campuran didasarkan atas ketentuan Pasal 57 UU No.1 Tahun 1974 tentang Perkawinan, yang menetapkan percampuran hanya dapat dilakukan karena perbedaan kewarganegaraan.

Bila yang dicampur dalam keluarga itu berbeda agama, mereka harus melangsung perkawinannya ke luar Indonesia, dengan syarat negara yang bersangkutan membenarkan adanya kawin beda agama dan bagi WNI tidak boleh melanggar syarat perkawinan di Indonesia. Syarat pertama mengakibatkan perkawinan membutuhkan biaya tinggi (karena harus ke luar Indonesia), sedangkan syarat kedua yaitu tidak melanggar syarat kawin di Indonesia. Sedangkan di Indonesia tidak boleh kawin beda 
agama.

Syarat kedua inilah menimbulkan keraguan akan sahnya suatu perkawinan. Selain itu, jika berpegang kepada sahnya suatu perkawinan didasarkan atas adanya pencatatan, juga tidak menghapus keraguan itu, karena sebagai pejabat negara, tentu tidak akan mencatat perkawinan yang melanggar syarat perkawinan menurut undang-undang. Ketentuan perkawinan campuran yang dianut oleh UU No.1 Tahun 1974 tentang Perkawinan bersifat ambigu. Satu sisi boleh asal dilakukan di luar Indonesia, dan sisi lain dengan syarat tidak boleh melanggaar syarat perkawinan di Inonesia.

Bila memperhatikan unsur syarat (bagi WNI) ditetapkan bahwa "bagi warganegara Indonesia tidak melanggar undang-undang ini". Undangundang ini maksudnya UU No.1 Tahun 1974, tentang Perkawinan, Pasal 2 ayat 1, yang menyatakan "Perkawinan adalah sah apabila dilakukan menurut hukum masing-masing agamanya dan kepercayaannya itu".

Ketentuan pasal ini, yang secara singkat dikatakan secara kontradiktif melarang perkawinan beda agama. Hal ini ditegaskan dalam kesimpulan tulisannya Ichtianto menyatakan bahwa sebagai undang-undang yang dibentuk berdasarkan dan bercita hukum Pancasila UUP memberikan kekuatan berlaku hukum perkawinan agama-agama yang dipeluk penduduk Indonesia. Tidak ada perkawinan yang dilangsungkan di luar hukum Agama. ${ }^{24}$

Kontradiksi antar pasal dalam satu perundang-undangan telah menunjukkan adanya sikap kompromistis yang secara formal sangat tidak mempedulikan nilai-nilai metode pembuatan perundang-undangan secara benar, yakni terpenuhinya asas konsistensi, harmonisasi, sistematisasi dan sinkronisasi. ${ }^{25}$ Dan sebagai kesimpulan akhir ia menyatakan bahwa ditinjau secara material, Undang-Undang No. 1 Tahun 1974 yang tidak memberikan kepastian hukum secara memadai terhadap pihak-pihak yang akan melangsungkan perkawinan beda agama, sudah dapat dikatagorikan sebagai kurang menghargai HAM²6

24 H. Ichtianto, Laporan Akhir Analisis dan Evaluasi Hukum 20 Tahun Pelaksanaan Undangundang Perkawinan. Proyek Pusat Perencanaan Pembangunan Hukum Nasional Badan Pembinaan Hukum Nasional Departemen Kehakiman RI Tahun 1994/1995. hlm.195.

${ }^{25}$ Murdiati Trisnaningsih, Relevansi kepastian Hukum dalam mengatur Perkawinan Beda Agama di Indonesia. (Bandung: CV. Utomo, 2007), hlm. 141.

26Murdiati Trisnaningsih, Relevansi kepastian...., hlm. 141 
Adanya unsur syarat ini seharusnya menjadi penghalang perkawinan WNI beda agama yang diselenggarakan di luar Indonesia. Namun dalam praktek unsur syarat yang belakangan ini diabaikan, seperti yang dilakukan oleh selebritis Yuni Shara dengan pengusaha Hendrik Siahaan di luar Indonesia (Australia), dan Dimas Anggara dan Nadine Chandrawinata yang dilangsungkan di Bhutan.

Mengingat keabsahan suatu perkawinan berdasarkan UUP Pasal 2 ayat 1 haruslah dicatat (termasuk perkawinan campuran dan perkawinan yang dilakukan diluar negeri), maka ayat 2 Pasal 56 menyatakan bahwa “Dalam waktu 1 (satu) tahun setelah suami isteri itu kembali di wilayah Indonesia, surat bukti perkawinan mereka harus didaftarkan di Kantor Pencatatan Perkawinan tempat tinggal mereka".

Mengenai pencatatan inipun, terdapat masalah bila kita telaah, yaitu yang dicatat tentunya perkawinan yang sah. Menjadi keliru bila Pegawai Pencatat Perkawinan mencatat atau mendaftar perkawinan yang tidak sah. Dengan uraian belakangan ini bila perkawinan yang diselenggarakan di luar Indonesia bertentangan dengan Pasal 2 ayat 1 UUP, berarti tidak sah (seperti diuraiakan di atas), maka jika begitu keadaannnya pendaftarannya perkawinan Yuni Shara-Henrik Siahaan, dan Dimas Anggara-Nadine Chandrawinata seharusnya ditolak di Idonesia. sehingga tidak dapat memegang surat bukti kawinnya. Perkawinan merupakan lembaga mulia yang tidak boleh dijadikan sarana untuk penyelundupan hukum.

Bagi orang Islam sahnya perkawinan adalah apabila dilakukan menurut Hukum Islam, sedangkan pencatatan perkawinan hanya sebagai kewajiban administratif belaka. ${ }^{27}$ Sehingga akan menimbulkan suatu kesalahan besar bagi sebagai orang muslim jika ia hanya mengejar sesuatu dengan cara menghalalkan segala hal hanya untuk memenuhi kebutuhan administratif saja tanpa memerhatikan keabsahan pada agama yang dianutnya.

Perkawinan campuran haruslah tegas dan mudah dilaksanakan serta dengan biaya ringan, seperti yang pernah berlaku di Indonesia dengan sebutan singaka GHR itu. Apabila tidak demikian maka sulit pertanggungjawabannya dari aspek hukum maupun HAM sebagaimana disinggung dalam Bab XA Pasal 28B ayat 1 Undang-Undang Dasar

27 Neng Djubaedah, Pencatatan Perkawinan dan Perkawinan tidak Dicatat (Jakarta: Sinar Grafika, 2010), hlm. 214. 
Negara Republik Indonesia Tahun 1945 yang menyatakan bahwa "Setiap orang berhak membentuk keluarga dan melanjutkan keturunan melalui perkawinan yang sah". ${ }^{28}$

Keabsahan yang dimaksud pada pasal tersebut harus sah secara agama dan secara hukum negara. Dengan ulasan kedua peraturan tersebut di atas diharapkan dapat diambil hikmahnya dalam pembentukan peraturan untuk waktu yang akan datang di bidang sinkronisasi pasal-pasal dan dapat dijadikan pertimbangan revisi peraturan yang tak mampu memberi solusi dari perbedaan.

\section{Pencatatan Perkawinan sebagai Penentu Keabsahan Perkawinan di Indonesia}

Pencatatan perkawinan memang merupakan kewajiban setiap Warga Negara Indonesia atau pemerintah (ulil amri). Tetapi tingkat kewajiban orang Islam Indonesia kepada (pemerintah) ulil amri itu tidak disertai dengan memperlemah atau memperlumpuhkan Hukum Perkawinan Islam yang sah, yaitu perkawinan yang memenuhi syarat dan rukunnya. Sebagaimana yang ditentukan oleh al-Quran dan al-Hadits.

Menurut Prof. Dr. Bagir Manan, mantan Ketua Mahkamah Agung Republik Indonesia, dalam memahami status hukum perkawinan antarorang Islam di Indonesia, harus diketahui terlebih dahulu asas legalitas (legality beginsel) yang mendasari keberlakuan Hukum Perkawinanbagi orang Islam di Indonesia. Asas legalitas (legality beginsel) berarti setiap perbuatan (tindakan hukum) harus atau wajib mempunyai dasar hukum tertentu yang telah ada sebelum perbuatan hukum itu dilakukan. ${ }^{29}$

Suatu perbuatan hukum yang sah, menurut Bagir Manan mengandung makna bahwa hubungan hukum dan akibat hukum menjadi sah pula. Dalam perbuatan hukum yang sah sehubungan dengan dilakukannya perkawinan yang sah antara seorang laki-laki dengan seorang perempuan menunjukkan bahwa pasangan suami istri tersebut adalah sah, demikian pula dengan akibat hukum lainnya. ${ }^{30}$

\footnotetext{
28 Abdurrahhman, "Perkawinan Beda Agama dan Implikasinya,"makalah, disajikan pada Kompendium Bidang Hukum Perkawinan Kementrian Hukum dan HAM, tanggal 12 September 2011, hlm. 31.

${ }^{29}$ Bagir Manan, "Keabsahan dan Syarat-Syarat Perawinan antarprang Islam menurut UU No 1 Tahun 1974" makalah dlm seminar "Hukum Keluarga dalam Sistem Hukum Nasional antara Realitas dan Kepastian Hukum, pada hari Sabtu, 1 Agustus 2009, hlm. 1.

30Bagir Manan, "Keabsahan dan Syarat-Syarat...hlm, 2.
} 
Perkawinan yang sah adalah perkawinan yang memenuhi ketentuan pasal 2 ayat (1) UUP Indonesia, yaitu sah menuru agama, yang mempunyai akibat hukum yang sah pula. Pencatatan perkawinan, sebagaimana ditentukan dalam pasal 2 ayat (2) UUP Indonesia tidak menunjukkan kualifikasi sederajat yang bermakna sahnya perkawinan menurut agama adalah sama dengan pencatatan perkawinan. Sehingga yang satu dapat menganulir yang lain.

Menurut Bagir Manan "tidak demikian"31. Bagir Manan berpendapat bahwa perkawinan menurut masing-masng agama (syarat-syarat agama) merupakan syarat tunggal sahnya suatu perkawinan, dengan alasanalasan sebagai berikut: ${ }^{32}$

Pertama, pasal 2 ayat (1) dengan tegas menyebutkan, "suatu perkawinan sah apabila dilakukan menurut masng-masing agama". Suatu rumusan yang sangat jelas (plain meaning), sehingga tidak mungkin ditafsirkan, ditambah atau dikurangi.

Kedua, pasal 2 ayat (2) menyebutkan, "Pencatatan tiap-tiap perkawinan adalah sama halnya dengan pencatatan peristiwaperistiwa penting dalam kehidupan seseorang, misalnya kelahiran, dan kematian.

Ketiga, penjelasan pasal 2 ayat (2), pencatatan kelahiran, pencatatan kematian, demikian pula pencatatan perkawinan sekedar dipandang sebagai suatu peristiwa penting, bukan suatu peristiwa hukum. Gunung meletus adalah peristiwa penting, tetapi bukan peristiwa hukum. Pesta perkawinan adalah peristiwa penting, bukan peristiwa hukum.. demikian pula pencatatan perkawinan menurut UUP Indonesia, bukan lagi peristiwa hukum atau syarat hukum, karena perkawinan sebagai peristiwa hukum ditentukan oleh agama.

Dalam hal alat bukti perkawinan, beliau menyatakan bahwa akta nikah dan pencatatan perkawinan bukan satu-satunya alat bukti mengenai adanya perkawinan atau keabsahan perkawinan, karena itu, akta nikah dan pencatatan nikah adalah sebagai alat bukti tetapi bukan alat bukti yang menentukan. Karena yang menentukan keabsahan suatu perkawinan adalah perkawinan menurut agama. Maka dengan demikian, alat bukti perkawinan juga harus tidak bertentangan dengan agama. ${ }^{33}$

Fungsi dan kedudukan pencataan perkawinan, menurut bagir Manan, adalah untuk menjamin ketertiban umum (legal order) yang berfungsi sebagai instrumen kepastian hukum, kemudahan hukum, disamping

\footnotetext{
${ }^{31}$ Bagir Manan, "Keabsahan dan Syarat-Syarat...hlm, 4.

${ }^{32}$ Bagir Manan, "Keabsahan dan Syarat-Syarat...hlm, 5.

${ }^{33}$ Bagir Manan, "Keabsahan dan Syarat-Syarat...hlm, 6.
} 
sebagai salah satu alat bukti perkawinan. ${ }^{34}$

Pendapat Bagir Manan tersebut didukung oleh doktrin-doktrin dalam HPI yang menyebutkan fungsi doktrin ketertiban umum, yaitu: ${ }^{35}$

1. Fungsi positif: yaitu menjamin agar aturan-aturan tertentu dari lex fori tetap diberlakukan (tidak dikesampingkan) sebagai akibat dari pemberlakuan hukum asing yang ditunjuk oleh kaidah HPI atau melalui proses pendekatan HPI, terlepas dari persoalan hukum mana yang seharusnya berlaku, atau apa pun kaidah lex fori yang bersangkutan.

Dari fungsi ini, bisa diambil kesimpulan bahwa keabsahan perkawinan yang dibuktikan dengan akta perkawinan yang dikeluarkan oleh District Registrar's Office, Perth, Western Australia dan catatan sipil Singapura, tidak dapat diakui keabsahannya di Indonesia karena bertentangan dengan hukum nasional Indonesia. Yuni Shara-Henrik Siahaan, dan Dimas Anggara-Nadine Chandrawinata melakukan penyelundupan hukum untuk mengesampingkan pemberlakukan pasal 2 ayat (1) UUP Perkawinan Indonesia.

Pegawai catatan sipil seharusnya juga mempertimbangkan kaidah ketertiban umum ini sebelum memutuskan untuk mengeluarkan akta perkawinan bagi Yuni Shara dan Bunga. Karena perkawinan mereka yang pun dilakukan diluar negeri, sebenarnya juga tidak memenuhi ketentuan pasal 56 ayat (1) UUP Indonesia.

2. Fungsi negatif, yaitu untuk menghindarkan pemberlakuan kaidahkaidah hukum asing jika pemberlakuan itu akan menyebabkan pelanggaran terhadap terhadap konsep-konsep dasar lex fori.

Penolakan terhadap kaidah hukum asing yang dalam hal ini berkaitan dengan kaidah hukum yang berlaku di Australia dan Singapura tak lain adalah untuk menghindari pelanggaran konsep regulasi yang ada dan berlaku di Indonesia.

Oleh karena itu, jika terjadi pasangan yang telah melakukan perkawinan yang sah menurut pasal 56 ayat (1) UUP Indonesia, seperti yang dilakukan oleh Yuni Shara-Henrik Siahaan, dan Dimas AnggaraNadine Chandrawinata, tetapi bertentangan dengan ketentuan dalam

\footnotetext{
34Bagir Manan, "Keabsahan dan Syarat-Syarat...hlm, 6.

${ }^{35}$ Bandingkan dengan Rooij, Rene Van, Private Internasional Law in the Netherland, 1987, hlm. 237-238.
} 
Hukum Islam, maka seharusnya pegawai pencatat perkawinan tetap menolak perkawinan tersebut. Karena ketentuan pasal 2 ayat (1) dan (2) dalam UUP tersebut, pada hakikatnya juga menyatakan demikian.

Perkawinan menurut hukum masing-masing agama berdasarkan pasal 2 ayat (1) adalah merupakan "peristiwa hukum". Peristiwa hukum tidak dapat dianulir oleh adanya "peristiwa penting" yang ditentukan dalam pasal 2 ayat (2), bahwa "tiap-tiap perkawinan dicatat menurut peraturan perundang-undangan yang berlaku". 36 jadi bagi orang Islam, sahnya perkawinan adalah apabila dilakukan menurut Hukum Islam, sedangkan pencatatan perkawinan hanya sebagai kewajiban administrasi

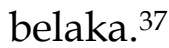

Penggunaan pasal dalam UUP Indonesia harus dianalisis secara komprehensif, dan tidak boleh ditafsirkan secara parsial. Karena pada hakikatnya, penggunaan pasal yang parsial berpotensi menimbulkan konflik dan bertentangan dengan konsep ketertiban umum dalam Hukum Perdata Internasional.

\section{Penutup}

Penyelundupan hukum dalam perkawinan bagi WNI belum teregulasi dalam sebuah peraturan perundang-undangan. Kasus penyelundupan hukum yang ada di Indonesia diselesaikan menggunakan pasal 56 ayat (1) UUP no 1 tahun 1974. Hal ini dikarenakan pihak terkait, yang dalam permasalahan ini adalah pegawai catatan sipil dan KUA berasumsi bahwa pelaku penyelundupan hukum sama dengan pelaku perkawinan campuran dalam pasal 57 ayat (1) dan (2).

UUP Indonesia disahkan pada tahun 1974 sedangkan term penyelundupan hukum itu sendiri baru dikenal oleh HPI pada tahun 1986. Hukum yang ada (UUP Indonesia) tidak mengikuti perkembangan kasus yang ada dalam masyarakat. Sehingga terjadilah kekosongan hukum, tidak ada peraturan yang mengatur tentang penyelundupan hukum. Hal inilah yang menyebabkan ambiguitas dalam pengaturan. Penyelundupan hukum disamakan dengan perkawinan campuran. Penyelundupan hukum memang bagian dari perkawinan campuran, nyamun dua permasalahan ini tidak dapat diselesaikan menggunakan aturan yang sama.

${ }^{36}$ Hazairin. Demokrasi Pancasila,cet 5 (Jakarta:Bina Aksara, 1985), hlm. 158.

${ }^{37}$ Djubaedah, Neng, Pencatatan...hlm. 214. 
Perkawinan yang dilakukan oleh pelaku penyelundupan hukum tidak sah baik secara agama maupun secara administratif hukum perkawinan nasional Indonesia. Penyelundupan hukum juga bertentangan dengan ketertiban umum dalam doktrin HPI, dan bertentangan dengan regulasi UUP Indonesia.

\section{Daftar Pustaka}

Departemen Kehakiman Republik Indonesia, Direktorat Jenderal Hukum dan Perundang-undangan, Sekitar pembentukan Undnag-Undang Perkawinan beserta Peraturan Pelaksanaannya.Jakarta: Direktorat jenderal Hukum dan Perundang-undangan

Marriage act 1961, Act No 12 of 1961 as amended, 2006, secsion 88 D

Undang-Undang No 1, Tahun 1974, Tentang Perkawinan

Undang-undang No.23, Tahun 2006, tentang Administrasi Kependudukan Ahmad Sukarja. Perkawinan Berbeda Agama Menurut Hukum Islam, Edito

Chuzaimah T Yanggo, \& Hafiz Anshary, Problematika Hukum Islam Kontemporer, Jakarta: PT Pustaka Firdaus, 1996.

Asaf. Pokok-Pokok Hukum Islam. Jakarta:Tinta Mas, 1965,hlm. 109.

Bayu Seto Hardjowahono. Dasar-dasar Hukum Perdata Internasional. buku kesatu edisi keempat. Bandung:PT Citra Aditya Bakti, 2006.

Budyapranata. Membangun Keluarga Kristiani. Yogyakarta: Kanisius, 1986.

Dzulfa Djoko Basuki, Hukum Perkawinan di Indonesia, Jakarta: Badan Penerbit Fakultas Hukum Universitas Indonesia, 2010.

Hazairin. Demokrasi Pancasila. cet.5. Jakarta: Bina Aksara,1985.

Hilman Hadikusuma. Hukum Perkawinan Indonesia menurut Perundangan, Hukum Adat, Hukum Agama. Bandung: Mandar Maju, 2007.

Husein Sayuti. Pengantar Metodologi Riset. Jakarta: Fajar Agung, 1989.

Jawahir Thintowi dan Pranoto Iskandar. Hukum Internasional Kontemporer. Bandung: PT. Refika Aditama, 2006.

Johnny Ibrahim. Teori dan Metodologi Penelitian Hukum Normatif. Malang:Bayumedia Publishing, 2011.

John Z Loude, Menemukan Hukum Melalui Tafsir dan Fatwa. Jakarta:Bina Aksara, 1985.

Martin Dixon. Textbook on Internasional Law. London:Blackstone Press, 1996.

Mertokusumo, Sudikno. Metode Penemuan Hukum. Yogyakarta:UII Press, 2006.

Murdiati Trisnaningsih. Relevansi kepastian Hukum dalam mengatur 
Perkawinan Beda Agama di Indonesia. Bandung: CV. Utomo, 2007.

Neng Djubaidah. Pencatatan Perkawinan dan Perkawinan tidak Dicatat. Jakarta: Sinar Grafika, 2010.

Sudargo Gautama. Warga Negara dan Orang Asing, cet-IV. Bandung:Alumni, 1987.

. Hukum Antar Tata hokum. Bandung:Alumni, 1996. . Segi-Segi Hukum Peraturan Perkawinan Campuran (Staatsblad 1898 No. 158). Bandung: PT Citra Aditya Bakti, 1996.

. Hukum Perdata Internasional Indonesia. jilid II bagian 3 buku ke-4. Bandung: PT Alumni, 1998.

Sution Usman Adji, Kawin Lari dan Kawin Antar Agama. Yogyakarta:Liberty, 2002.

Soehardi. Pengantar Hukum Adat Indonesia. Bandung:Van Hoove, 1954.

Soerdjono Soekanto. Penelitian Hukum Normatif. Jakarta:PT. Raja Grafindo, 2003.

Soetojo Prawirohamidjojo. Pluralisme dalam Perundang-Undangan Perkawinan di Indonesia. Surabaya: Airlangga University Press, 2006.

Syaikh Faisal bin 'Abdul Aziz' Al-Mubarok. Nailul Authar, terj. A. Qadir Hassan, Cet. I. Surabaya:Bina Ilmu, 1984.

Peter Mahmud Marzuki, Penelitian Hukum, Jakarta: Kencana Prenada Media Group, 2010.

Puja Gde. Hukum Kewarisan Hindu yang diresepsir ke dalam Hukum Adat di Bali dan Lombok. Jakarta:CV Junasco, 1974.

Ter Haar. Asas-asas dan Susunan Hukum Adat. Terj. Soebakti Poesponoto, Jakarta: Paramitra, 1960.

Wahyoko Darmabrata. Hukum Perkawinan dan Keluarga di Indonesia, cet-II. Jakarta:Badan Penerbit Fakultas Hukum Universitas Indonesia, 2004.

Zainuddin Ali. Metode Penelitian Hukum. Jakarta: Sinar Grafika. 2011.

Zainuddin Ali. Hukum Perdata Islam di Indonesia. Jakarta: Sinar Grafika, 2006.

Nurul Hasanah, Konstelasi Perkawinan Campuran Dalam Peraturan Perundang-Undangan Di Indonesia, skripsi, (Malang: Fakultas Syariah, Universitas Islam Negeri Maulana Malik Ibrahim Malang, 2010

Ira Rasyid, Tinjauan Perjanjian Perkawinan terhadap Perkawinan Campuran Warga negara Indonesia-Warga Negara Australia yang dilangsungkan di New South Wales-Australia, tesis,(Jakarta:Universitas Indonesia, 2013

Damerianti Purba, Analisis Hukum Perkawinan Campuran Dalam Status 
The Indonesian Journal of Islamic Law and Civil Law

Vol. I, No. I, April, 2020, ISSN. Xxx - xxx

Kewarganegaraan Menurut Undang-Undang Nomor 12 Tahun 2006, skripsi, Pematangsiantar: Fakultas Hukum Universitas Simalungun (Usi) Pematangsiantar, 2012

Sierly Natalia Nauli Siregar, Perkawinan Serta Perjanjian Perkawinan bagi Perkawinan Campuran yang Dilangsungkan di Luar Negeri Menurut Hukum Positif di Indonesia , skripsi, Bandung:Fakultas Hukum Universitas Padjajaran Bandung, 2013. 